\title{
Vitalitec International, The Sternal Closure Device: A novel closure technique for sternal dehiscence
}

\section{Sternal ayrılma için yeni bir kapatma tekniği: Vitalitec International, sternal kapama cihazı}

Aydın Tunçay, Yiğit Akçalı, Rifat Özmen, Özer Gazioğlu, Faruk Serhatlıoğlu

\begin{abstract}
Objective: Impaired sternal wound healing remains problematic after median sternotomy and can cause to significant morbidity after cardiac surgical procedures. Although some reconstruction systems exist for sternal closure, their use is limited by expense and practicality, and simple wire closure remains the most common technique to close the sternum. In this study, we aim to discuss the results of 6 cases that underwent surgery for sternal dehiscence(SD).
\end{abstract}

Methods: We reviewed six patients with sternal dehiscence who underwent surgery in our department between April 2013 and May 2014. We have used a novel closure technique in six patients with sternal dehiscence and evaluated early-term results of sternal clips plus rewiring following failed sternal closure.

Results: The mean age was 63 (range, 55 to 79 years). All patients were male. We have used a novel closure technique with sternal clips plus rewiring in all patients. We evaluated six patients with non-infectious SD. Sternal reconstruction using rigid fixation with clips improve bone healing and reduce early postoperative pain. All cases were discharged with successful treatment.

Conclusions: We believe that this method of sternal closure guarantees better clinical outcomes rather than sternal wire closure. Additionally, SCD(sternal closure device) clips proved to be cost effective in cardiac surgery. J Clin Exp Invest 2014; 5 (4): 534-538

Key words: Sternal dehiscence, closure technique, cardiac surgery

\section{INTRODUCTION}

Median sternotomy (MS) is the most common access to the heart and mediastinum used in cardiovascular surgery. Sternal dehiscence (SD) is a serious and potentially devastating complication that can cause pulmonary dysfunction, chest wall dis-

\section{ÖZET}

Amaç: Median sternotomi sonrası bozulmuş sternal yara iyileşmesi kardiak cerrahi sonrası önemli morbidite sebebi olabilir. Sternum kapatılması için bazı teknikler mevcut olmasına rağmen pratikte sınırlıdır ve sternumu basit tel tekniği ile kapatma uygulanan en yaygın tekniktir. Bu çalışmada sternal ayrılma nedeniyle cerrahi uygulanan 6 olgunun sonuçlarını tartışmayı hedefliyoruz.

Yöntemler: Nisan 2013 ile Mayıs 2014 arasında kliniğimizde sternal ayrılma nedeniyle opere edilen 6 hastaya sternal kapatma cihazı ile kapama uygulandı. Erken dönem sonuçları postop ağırı ve sternum sağlamlığı açısından değerlendirildi.

Bulgular: Ortalama yaş 63 (55-79 yıl) idi. Tüm hastalar erkekti. Enfekte olmayan sternal ayrılması olan 6 hasta değerlendirildi. Tüm hastalarda sternal klipsler kullanıldı. Klipslerle yapılan sternal rekonstrüksiyonda kemik iyileşmesinin geliştiği ve erken postoperatif ağrının azaldığı gözlemlendi. Tüm olgular tedavi sonucunda başarılı bir şekilde taburcu edildi.

Sonuç: Sternumun bu yöntem ile kapatılmasının tel ile kapatılmasına göre daha etkin ve daha iyi klinik sonuçlar verdiğine inanıyoruz, ayrıca kalp cerrahisinde sternal kapama klipslerin kullanılması daha düşük maliyetli olduğu görülmüştür.

Anahtar kelimeler: Sternal ayrılma, kapatma tekniği, kardiak cerrahi

comfort, superficial and mediastinal infections [1]. Sternal motion and instability may occur in the first days or weeks after MS owing to technical issues with the bone, wire, or surgical technique. This may resolve and heal normally, or it may lead to dehiscence because of fracture of the sternal bone or the 
sternal wires [2]. SD with or without infection can occur in $0.2 \%$ to $5 \%$ of patients as a result of primary nonunion, poor wound healing, or premature overexertion [2-7].

Certain patients are at a greater risk for experiencing sternal wound complications, and many studies have established both preoperative and operative risk factors. Previously reported preoperative risk factors for SD are obesity [2-8], Diabetes mellitus (DM) [9], chronic obstructive pulmoner disease (COPD) [2-9], chronic cough [10], smoking [2,3], New York Heart Association (NYHA) functional class [11] , osteoporosis [1,2], use of acetylcholinesterase (ACE) inhibitors [10],use of ß-adrenergic drugs for respiratory problems [11], immunosuppression [2-9], and previous sternotomy [9] . Operative risk factors are bilateral internal mammary artery (IMA) harvest [9], excessive amounts of blood transfusion [11], off-midline sternotomy [12], and prolonged cardiopulmonary bypass (CPB) time [3].

We describe six cases with complicated SD, treated with clips plus rewiring.

\section{METHODS}

We evaluated six patients with non-infectious SD (Table 1). Only one patient underwent an internal mammary artery (IMA) harvest. Routine sternal closure involved the placement of six to seven single sternal wires (no.5 or no. 6) with a multitwist closure.

The majority of patients experiencing SD presented with pain or instability of the sternum. SD was diagnosed with plain radiography and/or computed tomography (Figure1).

We have used a novel closure technique with sternal clips plus rewiring in our patients. The Sternal Closure Device (SCD) Vitalitec International (Inc.), Domalain, France is a novel device, which has been recommended for the prevention and cure of sternal pseudoarthrosis.

The device is produced in bio-compatible titanium alloy which enables Magnetic Resonance Imaging (MRI) techniques to be used. It is comprised of two hooks connected by a ratchet rod (Figure 2). One of the hooks is fixed at one end, while the second hook can be moved along the ratchet rod. A sternal closure applying forceps is used to bring to movable hook towards the fixed hook along the ratchet rod (Figure 2).

The SCDs are positioned perpendicular to the major axis of the sternum. The two hooks are ap- plied laterally to the sternum in the two matching intercostal spaces (Figure2).

The two intercostal spaces were dissected close to sternum using accepted surgical techniques in order to clear the two lateral edges of the sternum in the area to which the two hooks of the SCD will be applied. Attention should be paid not to damage the subjacent internal mammary artery, and not to make a subjacent pleural opening in the anterior mediastinal-costal recess; the applying forceps should be used to bring the two hooks towards one another such that the distance between the two hooks allows positioning of the SCD rod against the front surface of the sternum and the hook in the prepared parasternal intercostal space. Each hook is in contact with the lateral edge of the sternum; the shape, height and width of the hooks are designed to fit the sternum; When the 2 or 3 SCDs have been fitted, the positioning should be checked and, if necessary, the applying forceps should be used until the two sides of the sternum are compressed; the cutting forceps have to be used to cut off the excess rod at the base off the movable hook. If necessary a hemostatic compress can be positioned in the intercostal space in contact with the SCD to ensure hemostasis. The width of the hooks ensures sternal compression without cutting the sternum. If further surgery is required the SCD may be removed immediately either by using cutting forceps to cut the rack rod in two or by loosening the screw that fastens the fixed hook to the rod. The operating technique is identical for pseudoarthrosis. The technique should include a stage in which the two sides of the sternal bone are stripped until macroscopically healthy bone is reached before the SCD are used for the closing procedure.

\section{RESULTS}

We evaluated six patients with non-infectious SD. The mean age was 63 (range, 55 to 79) years). All patients were male. We have used a novel closure technique with sternal clips plus rewiring in our patients. In our cases, aortic valve replacement (AVR) was performed in one, mitral valve replacement (MVR) was performed in one and cardiopulmonary bypass graft (CABG) was performed in four patient. The SCD allows perfect, progressive sternal compression to be achieved (Table 1).

The main principle of the technique is 2 or 3 SCDs are required depending on the length of the sternum: one is applied to the manubrium and one or two others to the gladiolus. The sternal closure de- 
vices are shown post-procedure on the plain chest roentgenograms (Figure 1). The SCD enables uncomplicated sternal osteosynthesis to be per- formed, is easy to apply, and readily adapts to the shape of the sternum. All cases were discharged with successful treatment.

Table 1. Demographic, preoperative, and intraoperative variables

\begin{tabular}{|c|c|c|c|c|c|c|}
\hline Variable & Patient 1 & Patient 2 & Patient 3 & Patient 4 & Patient 5 & Patient 6 \\
\hline Age (year) & 55 & 58 & 55 & 71 & 79 & 61 \\
\hline Sex & M & M & M & M & M & M \\
\hline \multicolumn{7}{|l|}{ Risk factor } \\
\hline Obesity & - & - & - & + & + & + \\
\hline $\mathrm{BMI}\left(\mathrm{kg} / \mathrm{m}^{2}\right)$ & 27.9 & 27.4 & 32.3 & 36.5 & 32.3 & 27.6 \\
\hline Diabetes mellitus & - & - & + & + & + & + \\
\hline COPD & - & + & + & + & + & + \\
\hline $\mathrm{CHF}$ & - & + & + & + & + & - \\
\hline Urgency & - & - & + & - & + & - \\
\hline Smoking & - & - & - & - & - & - \\
\hline Osteoporosis & - & - & - & - & - & - \\
\hline Renal insufficiency & - & + & + & + & + & + \\
\hline Previous sternotomy & - & - & - & - & - & - \\
\hline \multicolumn{7}{|l|}{ Cardiac pathologies } \\
\hline Ischemic & CABG & & CABG & & CABG & CABG \\
\hline Valvular & & MVR & & AVR & & \\
\hline \multicolumn{7}{|l|}{ Intraoperative variables } \\
\hline Bilateral IMA harvest & - & - & - & - & - & - \\
\hline CPB time $>2$ hours (minutes) & 160 & 180 & 178 & 155 & 150 & 130 \\
\hline Cross-clamp time (minutes) & 65 & 45 & 46 & 70 & 70 & 50 \\
\hline Total operative time (minutes) & 245 & 255 & 249 & 240 & 240 & 210 \\
\hline Occurr. of dehiscence (days) & 48 & 14 & 15 & 14 & 30 & 30 \\
\hline
\end{tabular}

BMI: Body-Mass-Index, COPD: Chronic obstructive pulmonary disease,

CHF: Congestive Heart Failure, CABG: Coronary Artery Bypass Grafting, MVR: mitral valve replacement, AVR: aortic valve replacement, IMA: internal mammary artery, CPB: cardiopulmonary bypass

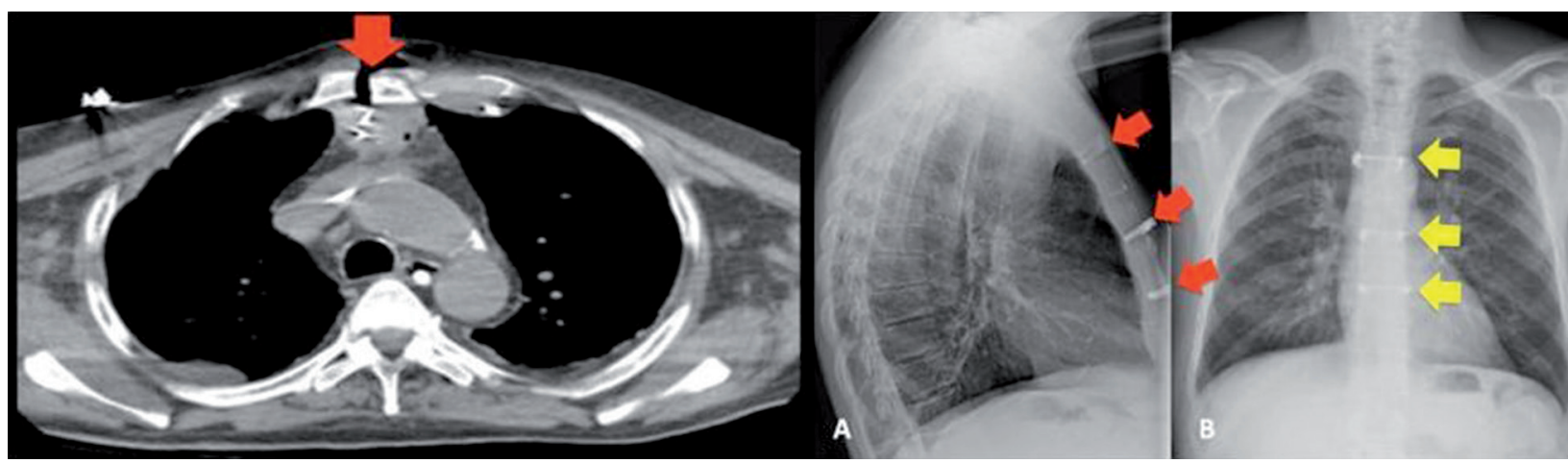

Figure 1. It is seen the sternal gap on the CT scan (red arrow)and the sternal closure devices are shown post-procedure on the plain chest roentgenograms: laterally (red arrows) and anteriorly (yellow arrows) 

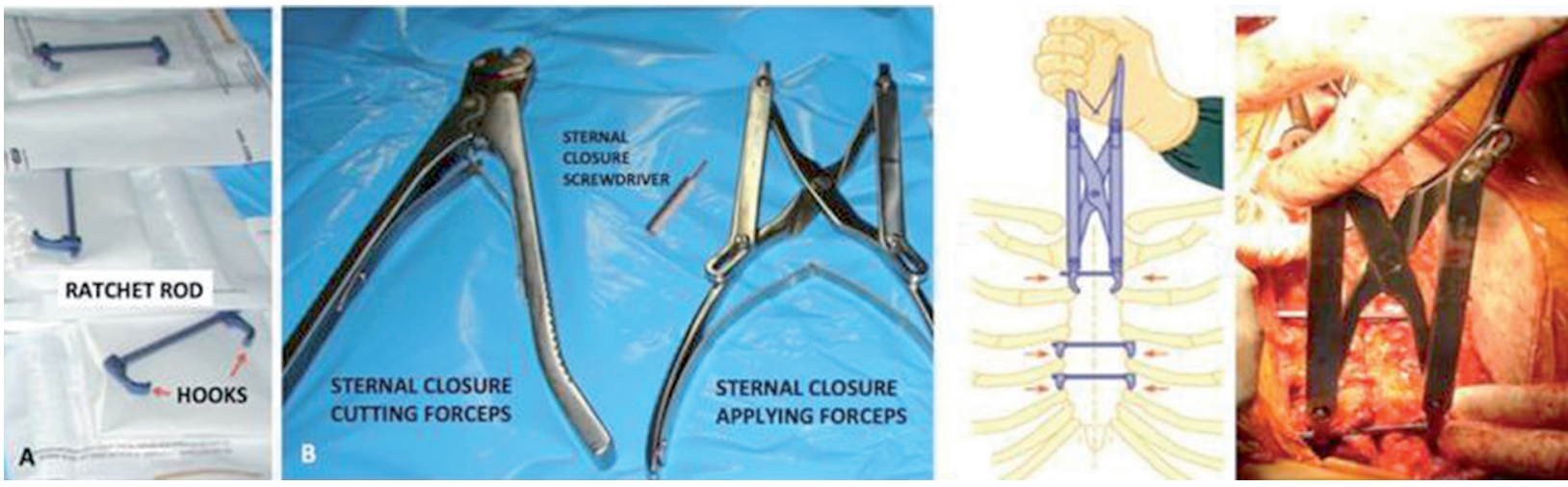

Figure 2. The Sternal Closure Device (SCD) (A) and its ancillary instruments: Sternal closure applying forceps (It is comprised of two jaws that are used to grip the two hooks of the SCD and bring them towards one another along the ratchet rod), sternal closure cutting forceps (It is used to cut off the excess ratchet rod at the base of the movable hook and to cut the middle of the ratchet rod in two in case immediate entry into the chest cavity is indicated), and sternal closure screwdriver (It is used to loosen the screw on the fixed hook in order to remove the device) (B)and a simplified operating technique

\section{DISCUSSION}

Despite the many advancements made in bone fixation and healing technology, the same method of sternal closure has been used for more than 100 years and is still the most common[13]. The use of sternal wire closure has been associated with various healing complications, such as instability, nonunion, and infections [14,15]. Thus, despite the modern progress in postoperative management, the incidence of this complication has remained stable over time. Sternal refixation can be performed by simple rewiring or technical modification of rewiring as described by Robicsek and colleagues [12] . When the bone quality is poor or there are multiple fractures of the sternum, these classical approaches of rewiring can fail and the rigid fixation systems, recently introduced, can be used for the sternal reconstruction [12-16].

Sternal dehiscence with or without infection is a serious complication after MS and it increases the mortality and morbidity rates [12]. When the bone is very osteopenic, the classical techniques of rewiring are associated with a high rate of recurrence SD. New approaches of sternal reconstruction, based on the use of orthopaedic, plastic and maxillofacial fixation systems, have been recently introduced. The sternal closure systems, consisting of titanium reconstruction plates, cables and screws, perform a transverse rib-to-rib stabilization without the adhesiolysis of the substernal area, extending the zone of fixation beyond the fractured sternum to the ribs laterally, where the bone quality should be better [12-16].
The Sternal Closure Device (SCD) (Vitalitec International, Domalain, France) does not require retrosternal maneuvers, so that the retrosternal structures are not endangered. Device positioning and placement is entirely performed from the anterior sternal aspect thus avoiding the risk of damaging cardiac, pulmonary or vascular (IMA) structures. The considerable width of the cramps placed in the intercostal space diminishes the danger of fracturing or cutting through the compacta of the sternum. In contrast to sternal wires the rectangular profile of the device is rotation-stable thereby securing the achieved positioning of the sternal part against each other allows for undisturbed consolidation. We have carefully assessed what was the better sternal refixation system to use in our cases.

In conclusion, we believe that this method of sternal closure guarantees better clinical outcomes. Additionally, SCD clips proved to be cost effective in cardiac surgery.

\section{REFERENCES}

1. Katz NM. Pericostal sutures to reinforce sternal closure after cardiac surgery. J Card Surg 1997;12:277-281.

2. Robicsek F, Fokin A, Cook J, et al. Sternal instability after midline sternotomy. Thorac Cardiovasc Surg 2000;48:1-8.

3. Losanoff JE, Richman BW, Jones JW. Disruption and infection of median sternotomy: a comprehensive review. Eur J Cardiothorac Surg 2002;21:831-839.

4. Bryan AJ, Lamarra M, Angelini GD, et al. Median sternotomy wound dehiscence: a retrospective case control study of risk factors and outcome. J R Coll Surg Edinb 1992;37:305-308. 
5. El Oakley RM, Wright JE. Postoperative mediastinitis: classification and management. Ann Thorac Surg 1996;61:1030-1036.

6. Harjula A, Jarvinen A. Postoperative median sternotomy dehiscence. Scand J Thorac Cardiovasc Surg 1983;17:277-281.

7. Casha AR, Yang L, Kay $\mathrm{PH}$, et al. A biomechanical study of median sternotomy closure technique. Eur $\mathrm{J}$ Cardiothorac Surg 1999;15:365-369.

8. Antoinette MJ, Rockx BA, Fox SA, et al. Is obesity a predictor of mortality, morbidity and readmission after cardiac surgery Can J Surg 2004;1:34-38.

9. Sharma R, Puri D, Panigrahi BP, et al. A modified parasternal wire technique for prevention and treatment of sternal dehiscence. Ann Thorac Surg 2004;77:210 213.

10. Abid Q, Podila SR, Kendall S. Sternal dehiscence after cardiac surgery and ACE type I inhibition. Eur J Cardiothorac Surg 2001;20:203-204.

11. Bitkover CY, Gardlund B. Mediastinitis after cardiovascular operations: a case-control study of risk factors. Ann Thorac Surg 1998;65:36-40.
12. Voss B, Bauernschmitt R, Albrecht W, et al. Sternal reconstruction with titanium plates in complicated sternal dehiscence. Eur J Cardiothorac Surg 2008 , 34:139-145.

13. Milton AF, cited by Kirschner M. [Tratado de tecnica operatoria general y especial.] Barcelona: Editoria Labor, 1942;4:756-760.

14. Taber RE, Madaras O. Prevention of sternotomy wound disruptions by use of figure-of-eight pericostal sutures. Ann Thorac Surg 1969;8:367-369.

15. Grossi EA, Culliford AT, Krieger $\mathrm{KH}$, et al. A survey of 77 major infectious complications of median sternotomy: a review of 7,949 consecutive operative procedures. Ann Thorac Surg 1985;40:214-223.

16. Huh J, Bakaeen F, Chu D, et al: Transverse sternal plating in secondary sternal reconstruction. J Thorac Cardiovasc Surg 2008;136:1476-1480.

17. Claus T, Kuehnel RU, Albes JM. Secondary closure of the sternum after healing of a postoperative mediastinitis using Sternal Closure Devices (Vitalitec International), Fumedica Medizintechnik, 2010. 